\title{
VOLUNTARY DISCLOSURE ON PT SEMEN INDONESIA TBK: LEGITIMACY CRISIS ON REMBANG PLANT CONSTRUCTION
}

\author{
Gentiga Muhammad Zairin ${ }^{1 *}$ and Elvia R. Shauki ${ }^{2}$ \\ ${ }^{1,2}$ Universitas Indonesia, Depok, Indonesia
}

\begin{abstract}
This study aims to evaluate how the legitimacy strategy was carried out by PT Semen Indonesia Tbk to repair the legitimacy due to the construction of the Rembang plant which was suspected of damaging the environment. Research problems arose due to inadequate company disclosures, resulting in a series of protests. This research has a contribution to understanding further how the company's strategy in facing the crisis of legitimacy. This research also uses web-based disclosure data and is processed with Nvivo 12 Pro software that has never been done before. This research uses legitimacy theory, especially strategies to repair legitimacy. This study uses case studies with triangulation of qualitative data and quantitative data, all of which are secondary data. Qualitative data in this study is the result of data processing using NVivo 12 Pro software from disclosure media such as annual reports, sustainability reports, websites, online-based newspaper, and corporate social media accounts. Quantitative data in this study include the number of words, number of sentences, and percentage of disclosures. The findings in this study were the strategy of "deny", "justify", "create monitors", "replace personnel", "revise practices", and "avoid panic" were used by companies. The strategy of "excuse" is not used because the company does not feel guilty. The dominant media used is a statement through the online-based newspaper. The use of social media and sustainability report shows very little legitimacy efforts.

Keywords: Legitimacy Crisis, Legitimacy Theory, Plant Construction, Repairing Legitimacy, Voluntary Disclosure
\end{abstract}

\section{INTRODUCTION}

The environment is a topic that is often discussed at this time, especially about sustainable development. Russell \& Thomson (2009) state that sustainable development is now a narrative that has been developed in many western countries and has become a lifestyle and form of social order. Moneva, Archel, and Correa (2006) state that before the 1980s, social issues and ecological issues were ignored in shaping management goals because they did not have a significant impact on the company's financial performance. After the Brundtland Report was introduced in 1987, the concept of sustainable development was widely implemented by companies in the world.

PT Semen Gresik (Persero) Tbk, was established on March 25, 1953, where the Government of the Republic of Indonesia had 51.01\% ownership of the company, while $48.99 \%$ of the remaining shares were public property. The company is engaged in the cement industry. The company has been listed as a public company on the Indonesia Stock Exchange (formerly the Jakarta Stock Exchange) since July 8, 1991, with a stock code: SMGR. On December 20, 2012, the company officially acted as the Strategic Holding Company and at the same time changed its name, from PT Semen Gresik (Persero) Tbk to PT Semen Indonesia (Persero) Tbk (PT Semen Indonesia Tbk, 2017), from now on referred to as PT Semen Indonesia.

Included in the series of refusal actions was the act of cementing the feet in front of the State Palace (cnnindonesia.com, 2016). This group came to be known as various names, such as Kendeng farmers, Kendeng activists, Kartini Kendeng, and others. Had subsided, the protests of these farmers occurred again in 2017. Precisely starting again on March 13, 2017, even, on a larger scale. More and more people sympathize with

* Corresponding author. Email address: gentigamz@outlook.com 
these farmers, both from within the country and abroad. Some people intentionally came to the action of cementing their feet and joined in trying to cement their feet as a form of solidarity with these farmers. This solidarity action was also carried out in Germany (bbc.com, 2017).

The action of cementing this leg then began to take casualties. After several people were disturbed by their health during the day-to-night protest, Patmi, one of the participants in the action died of a heart attack on March 21, 2017 (kompas.com, 2017). This incident increasingly attracted sympathy from the wider community. The protest which was initially attended by only nine people in 2016, in 2017 was carried out by hundreds of people in turn. The exposure of the media is indeed inevitable. The company's reputation is threatened with damage due to exposure to the preaching of these protests. The company experienced a legitimacy crisis over the construction of this Rembang cement plant and needed to restore its legitimacy so that plant construction could be continued. Moreover, the company has invested 4.9 trillion Rupiah to build this plant so that if the permit is revoked, the company will experience a significant loss (bisnis.com, 2017) where this will have an impact on the financial performance and performance of the company's shares, especially almost all the construction costs are financed by bank loans.

Eugénio, Lourenço, and Morais (2013) conducted a study of cement companies from Portugal whose legitimacy was disrupted due to the burning of waste and the location of the company's factories. The study uses sustainability reports and interviews with the company's internals as data to analyze disclosures made by the company. The results of the research are that several strategies can be found by the company reflected in the sustainability report. The limitations of this study are that other forms of disclosures other than sustainability reports are not examined and do not see the views of those outside the company.

Watson (2011) examined the conflict between the four largest diamond companies in South Africa and how the legitimacy of each was seen from the disclosures in the annual report. Furthermore, Watson (2011) found that changes in exposure or attention from the media were reflected in the disclosure of the company's annual report. However, Watson's research does not include web-based disclosures related to the legitimacy provided by the company.

Suchman (1995) defines legitimacy as a general perception or assumption on the actions taken by an entity so that the actions taken can be accepted by the social system that has been formed, for example from values, norms, and beliefs. Furthermore, this legitimacy has a goal in at least two dimensions - first, the purpose of continuity or the purpose of credibility. Second, the purpose of obtaining passive support or active support. Suchman (1995) also divided the legitimacy into three, namely: pragmatic legitimacy, moral legitimacy, and cognitive legitimacy.

According to the legitimacy theory, company behavior or activity is considered to have legitimacy when it has been deemed reasonable and deserves support from the social environment. Legitimacy gaps arise when the manager's expectations of social values of company behavior and social perceptions of the behavior are different (Deegan, Rankin, \& Tobin, 2002). In this case, the company needs to carry out a process of legitimacy both to gain legitimacy, maintain legitimacy, and improve the legitimacy to continue its operational activities (O’Donovan, 2002).

Meanwhile, if the company faces a legitimacy crisis due to an activity that occurs suddenly, the company needs to implement a strategy to improve legitimacy. Suchman (1995) explained that three strategies could be done when a company faced a crisis of legitimacy. First, making normalizing accounts that can take the form of denials, excuses, justifications, and explanations. Secondly, companies can restructure by establishing a better monitoring and supervision system or conducting disassociation with parties that have bad influences for the company. Third, companies must always be calm, careful, and avoid panic in making decisions regarding efforts to improve legitimacy. 
Based on the legitimacy theory, the company needs to take steps to legitimize the construction of the cement plant and prove that the cement plant does not damage the environment. One way that companies do is by voluntary disclosure. The company provides quite a lot of disclosure both in reports made and in the form of statements through the media. Laine (2005) says that disclosures made by companies can be seen as a medium or the way companies build social reality. Furthermore, Laine (2005) explains that there is a possibility of a relationship between disclosures made by the company and other efforts made by the company to legitimize its activities.

This study uses a case study approach and in general, will use content analysis assisted by using NVivo 12 Pro software. NVivo 12 Pro is software that can be used to process qualitative data in a very large number. All data are secondary data in the form of documents, online-based newspaper, websites, annual reports, sustainability reports, and other forms of disclosure such as the use of various corporate social media accounts. The social media studied, for example, are Facebook, Twitter, Youtube, Instagram, and others.

This research will focus on explaining how the legitimacy strategy used by PT Semen Indonesia Tbk in voluntary disclosures related to the construction and operation of a new plant in Rembang, Central Java to repair legitimacy and then attaining legitimacy again. Every disclosure given by the company will be analyzed by content to find out the legitimacy strategies that have been carried out. The analysis will also be carried out between periods of important events so that there will be a change in the issue or strategy that occurs.

\section{LITERATURE STUDY}

Eugénio et al. (2013) examined the cement company from Portugal (TimorL) whose legitimacy was disrupted due to environmental problems in the form of burning waste and the location of the company's plant. The study uses sustainability reports and interviews from internal parties as research data to analyze disclosures made by the company. The results of the study are that there can be found several strategies to improve the legitimacy of the companies reflected in the company's sustainability report.

The company is engaged in the cement industry which is very sensitive to social issues and environmental issues. Thus, it is likely that the voluntary disclosure practices of the company are inadequate if they only use sustainability reports. Not all corporate stakeholders have read or used sustainability reports. Therefore, the limitations of this study are that other forms of disclosures other than sustainability reports are not examined and do not see the views of those outside the company. The limitations of these studies will be overcome by exploring different forms of disclosure issued by companies such as information on websites, online-based newspaper, and corporate social media accounts. The interviews with managers are not carried out because this study will focus on the form of disclosure that is issued by the company and does not discuss the true intention of management.

Watson (2011) examined the conflict between the four largest gem companies in South Africa and how the legitimacy of each was seen from the disclosures in the annual report. Furthermore, Watson (2011) found that changes in exposure from the media were reflected in the disclosures of the company's annual report. However, Watson's research does not include web-based disclosures related to the legitimacy provided by the company.

Watson (2011) looks at research conducted by Branco, Eugénio, and Ribeiro (2008) which says that companies can overcome or respond to external impressions/issues by making disclosures on the internet, but annual reports are still the most important compared to the form other forms of disclosures. However, the research was done in 2008. The internet is now more accessible to all groups. Stakeholders will certainly seek faster disclosures compared to annual reports which 
are only issued once a year. Thus, the research that will be carried out will address this problem by examining all forms of disclosure in both annual reports, sustainability reports, and all types of disclosures that are web-based.

The concept of legitimacy is critical in analyzing the relationship between companies and the environment. Parsons (1960) defines legitimacy as an assessment of an action that is of general value or acceptable in the social context of society. Meanwhile, Maurer (1971) said that legitimacy is a process in which organizations try to justify the system concerning continuing the organization's right to keep, change, receive or send material or information.

Legitimacy is the result of congruence between the actions of institutions/companies with social values (Preston, Cooper, Scarbrough, \& Chilton, 1995). So, it can be said that legitimacy is an action that can be used by institutions to signal the similarity of values or even to change the social values that have existed. Legitimacy can be achieved by showing that company activities are under existing social values.

Legitimacy can be conducted in many different ways. First, companies must comply with applicable laws and regulations. Secondly, companies can create environmental committees or environmental managers to oversee the ecological impacts produced by the company. Third, companies need to build relationships with representatives of local communities around the company. Fourth, companies are encouraged to conduct environmental audits. Fifth, companies need to create a system to respond to emerging environmental problems. Sixth is aligning companies with environmental advocates (Bansal \& Roth, 2000).

The legitimacy theory is also highly concentrated on the concept of social contracts which has implications that a company must operate within the limits of prevailing social norms. Suchman (1995) considers legitimacy to be a general perception or assumption that the action of an entity is under the system of norms, values, beliefs, and definitions of the community around the company.

Suchman (1995) defines legitimacy into three types, namely pragmatic legitimacy, moral legitimacy, and cognitive legitimacy. Pragmatic legitimacy includes support for practices carried out by companies based on the consequences the company receives on these practices from the main constituents/audiences (O'Dwyer, Owen, \& Unerman, 2011). Pragmatic legitimacy is divided into three, namely: exchange legitimacy, influence legitimacy, and dispositional legitimacy.

This pragmatic legitimacy is very dependent on the main audience of the organization (Suchman, 1995). Often, this audience is very closely related to organizational activities. It is likely that the audience of the organization's activities will be a constituent, paying attention to all organizational activities and what consequences might arise from these activities (Wood, 1991). So, simply, this pragmatic legitimacy becomes exchange legitimacy, organizational policy will be based on how the values desired by its constituents (Dowling \& Pfeffer, 1975).

Slightly different from exchange legitimacy, Palazzo and Scherer (2006) explain that pragmatic legitimacy is not merely a matter of the relationship of one constituent party with the organization. Constituents can support things that do not fit the values they believe in, but they believe that the activities of the company represent greater interests. Influence legitimacy focuses more on broader constituent perceptions than the interests of smaller groups.

Suchman (1995) explained, in its development pragmatic legitimacy also developed into dispositional legitimacy. Organizations will increasingly be considered as an individual who has goals, values, and morals (Zucker, 1983). Thus, constituents will support organizations that have good values.

Moral legitimacy is legitimacy based on constituent assessment of the issues or practices that occur. These constituents will then assess whether the practice carried out by organization A is correct, or precisely wrong (O'Dwyer et al., 2011). Suchman 
(1995) divided this moral legitimacy into four major parts, namely consequential legitimacy, procedural legitimacy, structural legitimacy, and personal legitimacy.

Organizations must be assessed based on what has been achieved or has been achieved (Meyer \& Rowan, 1977). For example, an organization or company sells its goods in an impersonal market, where buyers assess the quality and value (two main factors) of the item. The buyers pay attention to the values of each producer. Furthermore, even in markets where competition is not tight, there will be an audience, usually from the regulator, who pays attention to specific activities carried out by the organization (W. R. Scott, 1977).

Brinkerhoff (2005) explains that procedural legitimacy is a practice that can be accepted socially by the constituents, then the practice is assessed by the constituents whether it has been appropriately implemented. Scott (1981) explains that a procedural legitimacy is a significant form of legitimacy when there are no clear outcomes for a practice. Furthermore, Scott (1981) argues that practices that are by procedures can show that the organization has taken the appropriate path so that legitimacy can be achieved.

In structural legitimacy, the audience sees the organization as something that should be supported because its structural characteristics match the moral taxonomy category that is carried out by the audience (W. R. Scott, 1977). Furthermore, the structure in question is social indicators that must be met when the company carries out specific activities. Different activities will have different social indicators, depending on the social conditions of the community. This legitimacy is also often referred to as categorical legitimacy (Zucker, 1986).

The final form of moral legitimacy is personal legitimacy. Suchman (1995) says that personal legitimacy is the legitimacy that arises from the charisma of individuals. The individual in question is usually the leader of the company, for example, the CEO or directors.

O'Dwyer et al. (2011) say that cognitive legitimacy is the legitimacy carried out by organizations so that constituents believe immediately that the activities carried out by the organization are by the rules, quite understandable, and indeed desired by the company. Suchman (1995) divides cognitive legitimacy into two, namely based on comprehensibility (understandability) and based on taken-for-grantedness.

Furthermore, O'Dwyer et al. (2011) explained that comprehensibility would depend on how to popularize the practice by creating cultural accounts that can provide a reasonable explanation of the practices carried out by the organization and how these explanations are carried out. Meanwhile, taken-for-grantedness is the most subtle way, even the most powerful source of legitimacy, but it is very difficult to achieve by the organization.

The three big groups of legitimacy above do not occur individually or independently in every issue/activity of the company. They are co-existed or exist together, and organizations try to gain legitimacy in these ways (Brinkerhoff, 2005). Ruef and Scott (1998) state that although the three types of legitimacy are mutually reinforcing, it is not uncommon for conflicts to occur between types of legitimacy.

Efforts to improve legitimacy are similar to attempts to gain legitimacy. The different thing is strategies to improve legitimacy reflect the reaction to a crisis. When managers begin to solve problems, perhaps the legitimacy is gone, so more effort is needed to repair legitimacy (Suchman, 1995).

Strategies to improve legitimacy are divided into three major groups: (a) offer normalizing accounts, (b) restructuring, and (c) do not panic. Even though legitimacy crises can be seen in company performance, the greatest challenges are in the failure of the company to maintain meaning and perception. The example in question includes: the audience begins to suspect that the output produced by the company contains dangerous ingredients or the audience suspects that there are procedures that are not carried out by the company. Therefore, the first task in improving legitimacy is to form normalizing accounts. That is, the company prepares various formulas to reduce threats 
to legitimacy so as not to spread to the company's overall assessment (Marcus \& Goodman, 1991; Scott \& Lyman, 1968).

Four types of normalizing accounts can be formulated by companies, namely: denials, excuses, justifications, and explanations (Ashforth \& Gibbs, 1990; Elsbach, 1994; Staw, McKechnie, \& Puffer, 1983). The first thing a manager can do is denying that there has been a problem with the company. Denial is done in the hope of being able to calm the (pragmatic) audience and at the same time prepare compensation. However, if the denial is wrong, the impact on the company's legitimacy is even more significant.

Therefore, managers can not choose to deny they decided to make excuses. In this case, moral legitimacy will be questioned. In the end, usually, individuals or external parties will be blamed. However, if it is not careful, the company will be deemed not to have a good control system (Ashforth \& Gibbs, 1990; Salancik \& Meindl, 1984; Staw et al., 1983; Sutton \& Callahan, 1987).

Next, to avoid the notion that the company does not have good control, managers can justify the problem. Redefine the problem so that it doesn't look like a problem. The problems that occur are then explained in other words which ultimately correspond to the moral and belief of the audience. When managers cannot provide denials, excuses, or justifications, managers can choose to offer explanations to the events as they are in the hope of protecting a little from cognitive legitimacy.

Furthermore, companies can conduct restructuring, as a step to restore legitimacy (Pfeffer, 1981). The negative impact of this method is that the company will look unstable (Hannan \& Freeman, 1984). There are two types of restructuring that the company can do. First, create a monitoring and monitoring system (creation of monitors and watchdogs). This can be done by asking for government activities to be regulated, determining ombudsperson, and making a proper complaints system (Pfeffer, 1981). This method cannot immediately restore legitimacy in its entirety, but it can show some constituents that they can continue pragmatic exchanges.

Second, do disassociation. This method is done by keeping companies away from "bad influence." The most common thing is to replace company executives because they can show the company's desire to change (Gephart Jr, 1978; Pfeffer, 1981; Weber, 1978). Besides, companies can also disassociate improper procedures and structures.

The last strategy managers can do when facing a legitimacy crisis is not to panic. That is, companies cannot panic in the face of problems. This is because, companies that have been disrupted by their legitimacy will be in a very sensitive environment (Staw et al., 1983). Companies that try to restore legitimacy in a panic will find it difficult to regain legitimacy, but if the same effort is carried out with caution, then the legitimacy may be saved (Ashforth \& Gibbs, 1990).

\section{RESEARCH METHODOLOGY}

The approach in this study is Case Study. Case studies are in-depth and contextual studies of a phenomenon or a case. For this study, the case study only examined one entity, PT Semen Indonesia Tbk. The case study conducted was to evaluate the disclosures made by the company in legitimizing the construction and operation of a new cement plant in Rembang, Central Java, which was suspected of damaging the environment.

The case study approach is used because this phenomenon is unique in PT Semen Indonesia Tbk. There are several other cement plants that have stood in the same mountainous area as the company's plant but have not received too much public attention. Besides, there were no "extreme" protests such as cementing the feet that were carried out to protest the company's activities. Thus, research on the cement foot action case is more appropriate to use a case study approach because the phenomenon is unique in PT Semen Indonesia Tbk only and occurs in a long time (divided into several periods). 
This research was conducted using the triangulation method or commonly called mixed-method. Data collection with triangulation can be interpreted as collecting data by combining various techniques of collecting data and existing data sources. The triangulation method in this study combines qualitative data and quantitative data to analyze disclosures made by the company in legitimizing its activities related to the construction and operation of a new plant in Rembang, Central Java.

This study only uses data triangulation. This study uses qualitative data and quantitative data, all of which are secondary data. Secondary data is data available to the public. Qualitative data in this study is in the form of data processing using NVivo 12 Pro software from documents such as the sustainability report of PT Semen Indonesia Tbk, annual reports of PT Semen Indonesia Tbk, online-based newspaper, and information on PT Semen Indonesia websites Tbk. Quantitative data in this study also uses NVivo 12 Pro software, but data in the form of numbers such as the number of words, number of sentences, number of paragraphs, and the amount of disclosure made by the company.

The research instruments used included annual reports, sustainability reports, websites, press remarks in the form of an online-based newspaper, and corporate social media accounts. The research instruments used included Annual Reports, Sustainability Reports, websites, press remarks in the form of an online-based newspaper, and corporate social media accounts. Both annual reports and sustainability reports used are from 2014 to 2017. Websites article are from 2014 to 2018. The onlinebased newspaper that is collected is from 2014 to 2018. Corporate social media accounts consisted of Facebook, Twitter, Youtube, Instagram, and LinkedIn. For social media accounts, data is collected from the moment the account is made public. Company's Facebook account is created in 2014, while other forms of social media are created later in 2015 and 2016.

The data in this study were analyzed by content analysis method. Bowen (2009) says that the use of content analysis in documents issued by companies is not only used to analyze CSR practices, but also to analyze corporate practices in general. Du and Vieira (2012) use content analysis to identify CSR strategies and CSR communication tactics by examining company pages/websites.

The analysis was carried out using NVivo 12 Pro software. NVivo 12 Pro is one of the software for processing information data in the form of text or other multimedia. Unerman (2000) states that content analysis can be used as a method to quantify disclosures. Content analysis can be used to better understand text-based data (Elo \& Kyngäs, 2008). Disclosures are often text-based that are difficult to measure using conventional calculations. This method can be used to measure the content of disclosures based on characters, words, sentences, pages, the proportion of disclosure contents, and others.

The content analysis carried out is divided into two. The first is the word frequency test. Its function is to get the most discussed ideas or issues in the media. Second is the text search test. Its function is to look for words that reflect the strategies that the company might use.

Word indicators used for the text search can be seen in Table 1. The words are taken from the Merriam-Webster dictionary which is then translated into Indonesian and adjusted according to the habits when people use Indonesian. After that, the theme will be analyzed based on which indicator words are used. The themes studied were only themes related to the company's legitimacy strategy. Also, the dominant disclosure media used in each company's legitimacy strategy was analyzed.

\section{RESULTS}

When companies make disclosures to legitimize their activities, companies need to know what issues are dominant in the media coverage. For this reason, an analysis of all the news in online-based newspaper-based newspapers is carried out. Because the research problem is about the construction of the Rembang cement plant, the 
keyword used to search related online-based newspaper is the "Rembang cement plant." These keywords are entered into the Google search engine. Based on Google's search results from 2014 to October 2018, there was at least 241 news related to the construction of the Rembang cement plant. The following is Figure 1 which shows a graph of the amount of online-based newspaper news that appeared in the period 2014 to 2018 .

Based on Figure 1, the number of news related to the construction of the Rembang cement plant in 2016-2017 is much higher than in other periods. Here, it appears that there is considerable media exposure to the case of the construction of the company's Rembang cement plant. Figure 1 indicates that there is a legitimacy crisis faced by the company. To find out more about the issues that develop from year to year, content analysis is carried out on the news.

Based on the results as presented in Figure 2, the three most dominant issues appear in the news in 2014, namely farmers, rejects, and the environment. Farmers around the plant construction site were the hardest to protest the construction of the plant. This is because farmers fear that their harvest will decline due to the activities of the cement plant. Thus, the company must make greater legitimacy efforts towards the farmers as constituents who are most affected by the company's operations.

Second, a term "protest" which is an issue of rejection of the construction of the Rembang cement plant. This rejection was carried out not only by farmers but also by other villagers, communities, NGOs and environmental activists. So, companies need to pay attention to these parties when making legitimate efforts. Next is the environmental issue, which in this case is the construction of a cement plant can damage the environment. However, in 2014 this environmental damage did not appear. Companies must make legitimate efforts to show that the construction of factories does not damage the environment.

In 2015, there was a shift in issues that developed in the media coverage. The most dominant issue is "investment." The company has issued substantial capital to build the new plant. If finally, the company cannot continue the construction of the Rembang cement plant, the company's investment will be lost. So, the company will try to legitimize to protect the investment that has been issued.

Environmental issues are also still a dominant issue. The company's cement plant is suspected to have damaged the water absorption area because of the location of the plant in the mountains. Companies must legitimize that the existence of a cement plant does not harm water absorption. The company can also offer policies or assistance as a consequence if it is true that the presence of a plant harms water absorption.

In 2016, as seen in Figure 2, environmental issues are still the most dominant issue because the exposure of the news is very massive. The company's efforts to make disclosures must be even greater because negative reporting on the environment is also quite large. In 2016, the term "Kendeng farmers" began to appear dominant. Kendeng is the village closest to the existence of the company's plant. This group is the company's main constituent whose legitimacy must be achieved at the earliest.

The issue of protest is still the same as that in 2014, except that the protest in 2016 was broader. While in 2016, this rejection has become a national issue. The indication is that the rejection in 2014 was only delivered around the construction site while the 2016 refusal was delivered in front of the State Palace. The company's efforts to legitimize its activities are getting heavier because more and more audiences to be heard.

The dominant issue in 2017 has not changed much compared to 2017. However, the issue of farmers is re-emerging due to the protests carried out at the State Palace; there was one farmer who died. The deceased farmer is one of those who participated in cementing the foot as a protest against the construction of a cement plant. The news made more audiences sides with the farmers as audience appeal to social issue more than an environmental issue. 
As shown in Figure 2, in 2018, no negative issues were found such as in 20142017. The dominant issue is precisely about aid or assistance. In 2018, the company gave a lot of aid to villages around the plant site. The most given help is water aid during the dry season. In the dry season the area is always difficult to water, so the presence or absence of the plant is not too influential. This step can be seen as a legitimate effort by providing something for the company's main constituents (pragmatic legitimacy).

The company is also active in carrying out other CSR activities such as workshops, renovating houses in villages around the plant, providing capital for MSMEs, and others. The company continues to take steps to improve and further maintain the legitimacy of the establishment of the Rembang cement plant. Based on the development of 2017 news reports until 2018, it can be said that the legitimacy efforts carried out were quite successful.

\section{DISCUSSION}

There are seven legitimacy strategies to be analyzed, namely: denial, excuse, justify, create monitors, replace personnel, revise practice, and avoid panic. The explain strategy is not analyzed because strategy explain is used to obtain cognitive legitimacy whose conditions require the audience to have a strong understanding of the company and the business activities carried out. Based on issues that are developing in the news and seeing parties protesting and the general public, the condition of cognitive legitimacy will be difficult to achieve.

\section{Denial}

Denial is a common strategy when a company is faced with a problem. Based on the results of the analysis in Table 2, it was found that the company had carried out a denial strategy in its efforts to restore the legitimacy of the construction of the Rembang cement plant. The two words that most often appear are the words "clarification" and "argue." In clarifying and arguing, companies use online news and websites more often. This media is more likely to be used because every time there are journalist questions, company representatives can immediately answer or give a rebuttal. The coverage of this denial strategy is not too high, which is around $3.03 \%$ of all disclosures made by the company.

In some arguments, the company alludes to some themes or issues. The first issue is that the company denies damaging the environment in locations around the plant. This is by the issues circulating in the news, where environmental issues are very dominant in the news coverage. The company's denial of environmental destruction is by the problems that need to be sought for its legitimacy.

Second, the news circulated that the farmers were the ones most affected by the construction of the plant. They feel disadvantaged over the construction of the plant and on behalf of several villages around the plant. However, this issue was denied by the company through the statement of the company's commissioners who directly visited villages around the plant. The rebuttal has answered the issue of rejection of farmers and citizens who often appear in the news.

\section{Excuse}

Based on the results of the analysis in Table 3, no company disclosures were found regarding the excuse strategy. Some indicators do find the use of words that show an attitude of looking for reasons, but after further analysis to look for themes, nothing is intended to legitimize the construction of factories. This indicates that the company did not feel guilty about the construction of this cement plant. This finding is by the research of Eugénio et al. (2013) that companies that do not use excuse strategy are companies that feel they have done nothing wrong or violated the rules. 


\section{Justify}

Based on the results presented in Table 4, it is seen that the company is trying to be quite large in justifying the construction of the cement plant. This can be seen from a fairly high coverage. The company uses almost all media disclosures to give justification but uses more means of statement through the press (news). This finding indicates that the company is trying to reach all stakeholders through a press statement to "fight" the issue in the news that has developed so far that the company is damaging the environment.

There are several themes promoted by the company in justifying. The most dominant theme is the concept of the Green Industry. This concept is often repeated in various media, such as the Annual Report, Sustainability Report, and through press statements. The company is trying to influence the audience that by implementing this concept, it is impossible for companies to be involved in environmental destruction.

The next dominant theme is the abundant harvest and the absence of drought. This needs to be explained by the company because previously the company was suspected of damaging water catchment areas which could harm farmers. The company tried to change the moral view of the audience who had thought that natural conditions were damaged by the plant, in fact, the results were not so. There are no droughts that hit people's farms, and the harvest of surrounding farmers has even increased.

The last major theme is about CSR and CID (Community Involvement and Development). The company also provides a lot of disclosures related to CSR and CID. By continuing to disclose CSR, it is expected that the audience will assume the company has a good attitude towards its environment. The CID concept is also often echoed, especially regarding this Rembang plant. The case for the construction of the Rembang plant gave the impression that there was a wide gap or gap between the existence of the plant (company) and the residents. The CID concept seeks to impress the general audience that cement factories and residents can work together and have harmonious goals.

\section{Create monitors}

Create monitors is one of the restructuring efforts aimed at showing the audience that the company will take steps to monitor the activity. Based on the results in Table 5 , it seems that there is not enough effort by companies to look to do something to prevent the same things from happening again in the future. According to Suchman (1995), companies will usually ask the government to make regulations or companies create special committees to oversee the activities of companies that are in trouble. Forming a new oversight committee is to signal to the audience that the company is fixing the problem of the activity.

Based on the results of the analysis, there is indeed an effort made. For example, the manager conducts socialization regarding the planned mining activities. This socialization invites various parties, such as residents who live near plants, community leaders, journalists, students from several schools in Rembang, and others. The socialization is to show the mining process carried out and explain that they do not damage the environment. Another effort is to encourage the community to be involved in making environmental permit because one of the causes of this problem is the result of a legal decision which states that the permit is defective and must be re-made.

Despite efforts made by the company, there is no real effort to create a better supervision system. So, it can be concluded that indeed the company does not feel that it has made a mistake and the few new monitoring efforts that are carried out are just a momentary gimmick.

\section{Replace personnel}

Replace Personnel is the company's effort to eliminate "bad influence" so that they feel the need to replace or dismiss these people. Based on the results of the analysis in Table 6, no attempt was made to replace people who were perceived as having a 
negative impact on the company. There are several reasons that might underlie this. The first reason is that there are no company directors or other internal parties guilty. The second reason is that the activities carried out are not problematic, but the lack of communication and disclosure to the public is the cause of the issue of developing wildly in the media.

Although there were no parties considered to be "bad influence" in the company, there was one replacement for the board of commissioners who had become media coverage. Sutiyoso, former governor of DKI Jakarta and former head of Indonesian State Intelligence Agency was appointed as the company's President Commissioner. There are assertions that this appointment is based on his experience in resolving conflicts while serving in the military and his ability in the field of bureaucracy.

The assertion was proven through Sutiyoso's report coming directly to the location around the plant and hearing how the residents responded to the construction of the plant. Sutiyoso began serving as President Commissioner in April 2017 and shortly after, he immediately came to the location of the Rembang plant. This was never done by the directors and board of commissioners before. In 2018, negative issues regarding the company disappeared from the media. Based on these findings, replace personnel does not merely explain the turn of the guilty person or "bad influence" but can also replace the good with the better.

\section{Revise practice}

Revising practice is usually done when the practices carried out by the company are not under applicable norms. The practice here can be seen regarding the law, procedure, or the impact that has been caused to the audience. It could be legally an activity is legal, but it is not following the norm of the audience around the activity. Then these activities can lose legitimacy.

This is likely to happen here because based on the findings in Table 7, there are very few revisions to practice. Coverages from "build" and "make" are indeed quite high, but after a more in-depth examination of the legitimacy theme, there are only two themes that emerge. First is the construction of Waste Heat Recovery Power Generator (WHRPG). This concept is included in the Green Industry concept that is carried out in the justification strategy.

Based on the results of the analysis of news issues in the Results Section, the environment, especially water availability, is the most dominant issue. The WHRPG concept was adopted by the company in 2016 or two years after the rejection of the Rembang plant began. WHRPG is generally a new technology to collect heat arising from the combustion process in the plant to be converted into electricity. In other words, waste heat and $\mathrm{CO} 2$ will decrease, and companies can produce electricity themselves.

Reduced waste heat and $\mathrm{CO} 2$ produced by the plant will certainly have a direct impact on the surrounding environment. The use of this technology will make agricultural land around the plant not dry. This is confirmed by reports that the yield of residents around the plant has increased. Even on websites, the company revealed that they would provide electricity for villagers around the plant from WHRPG. By involving citizens directly, damaged moral legitimacy can be restored. Concerns about damage to recharge and the availability of water can be controlled by the company.

The next theme is the construction of water reservoirs. Still, regarding water, the company is trying to make it easy for residents to get water. So, the company made several water reservoirs which happened to be also a program of the Governor of Central Java. In addition to meeting the needs of the surrounding community, the company also showed a Good Corporate Citizenship attitude towards the government.

\section{Avoid panic}

Avoid panic is just a general strategy that wants to remind managers and company executives to always act calmly despite facing a crisis. This is because, in a 
crisis, everything becomes sensitive. If the wrong action is made, the consequences will be enormous.

Based on the results of the analysis in Table 8, the executive has tried to maintain internal conditions and in the environment of the Rembang plant to remain conducive. This is shown through appeals both internally and externally. This appeal is needed so that if something happens, such as a protest in a plant environment, can hold back.

Company executives also often show that they hear all the aspirations of residents around the plant site. In a crisis, the company must be passive. In addition to avoiding mistakes when talking a lot of things, being passive will lower the temperature of the party who protests.

For example, in 2016 and 2017, when farmers protested by cementing their feet, the company could not "attack" the participants of the action. Commenting on the participants of the action will only heat the emotion of those who are protesting. When faced with such a situation, the company chose to concentrate on ongoing legal processes and immediately hear other constituents around the plant. People who did not take part in the protest did not necessarily support the existence of the plant, but communicating with residents who did not would be easier.

A calm attitude is also shown through the company's corporate strategy. As explained previously, the company has indeed denied allegations, especially regarding environmental damage. However, the company provides a rebuttal as needed. The denial that is expressed continuously will only increasingly show that there is something that the company wants to cover up. In general, the attitude to avoid corporate panic has been very good.

\section{CONCLUSION}

This study aims to provide an evaluation of strategies to repair the legitimacy of PT Semen Indonesia in voluntary disclosures related to the construction and operation of a new plant in Rembang, Central Java. Based on the results of research conducted on all research instruments, several conclusions are made. The "deny," "justify," "create monitors," "replace personnel," "revise practices" and "avoid panic" strategies were used by the company to repair the legitimacy due to the construction of the Rembang cement plant which was suspected of damaging the environment. The "excuse" strategy is not done because the company does not feel guilty. The "deny" strategy combined with "avoid panic," shows the company is innocent while maintaining the audience's emotions.

The "do not panic" strategy was shown by the CEO by appealing to his internal ranks to maintain conduciveness at the Rembang cement plant. This condition is needed as a form of caution because if there is violence, the legitimate narrative that is being built by the company will be damaged. A very minimal "create monitors" strategy is thought to be just a "gimmick" to get pragmatic legitimacy quickly. This gimmick is performed because the company does not feel that something is missing from the internal supervision system that has been built.

"Replace personnel" strategies are not carried out in the form of eliminating bad influence, which is usually done by dismissing board members or executives deemed responsible for the many protests that occur. Replace personnel strategy is done by recruiting boards that have high capability and good communication skills in the face of conflict. The new chief commissioner was able to solve the problem of building this Rembang plant.

The strategy of "justify" and "revise practice" are both used to obtain moral legitimacy. The "justify" strategy is shown by showing claims for the impact of the green industry policies that have been made. Example: agricultural land does not experience drought, even harvest increases. Meanwhile, "revise practice" is demonstrated by introducing the Waste Heat Recovery Power Generator (WHRPG) 
technology which can reduce combustion heat while providing electricity to surrounding villagers.

The dominant media used for repairing legitimacy is a statement through the press or online-based newspaper. Then websites and annual reports. The use of sustainability report is very minimal. The use of social media is also more about branding; it is not used as a means to legitimize issues.

Future studies may consider adding research instruments in the form of interviews. Interviews can be conducted on internal companies, such as managers or other executive ranks. Interviews with stakeholders (audience), both those that are close to company activities (ring-1) and with other broader stakeholders can also be considered. This can give an idea of how perceptions received by stakeholders from the legitimacy strategies undertaken by the company. So, the research can compare the planned intention and the view of the audience on the disclosure.

\section{References}

Ashforth, B. E., \& Gibbs, B. W. (1990). The double-edge of organizational legitimation. Organization Science, 1(2), 177-194.

Bansal, P., \& Roth, K. (2000). Why companies go green: A model of ecological responsiveness. Academy of Management Journal, 43(4), 717-736.

bbc.com, 2017, 'Aksi menyemen kaki di Jerman untuk petani Kendeng', bbc.com, 10 Mei, downloaded on 5 Oktober 2018, <https://www.bbc.com/indonesia/indonesia39871127>

bisnis.com, 2017, 'Menperin: Kepastian Investasi Semen Rembang Harus Dijaga, bisnis.com, 19 Maret, downloaded on 5 Oktober 2018, <http://industri.bisnis.com/read/20170319/257/638341/menperin-kepastianinvestasi-semen-rembang-harus-dijaga >

Bowen, G. A. (2009). Document analysis as a qualitative research method. Qualitative Research Journal, 9(2), 27-40.

Brinkerhoff, D. W. (2005). Organizational legitimacy, capacity and capacity development. University of Kansas. Public management research association (PMRA).

Branco, M. C., Eugénio, T., \& Ribeiro, J. (2008). Environmental disclosure in response to public perception of environmental threats: The case of co-incineration in Portugal. Journal of Communication Management, 12(2), 136-151.

Deegan, C., Rankin, M., \& Tobin, J. (2002). An examination of the corporate social and environmental disclosures of BHP from 1983-1997: A test of legitimacy theory. Accounting, Auditing \& Accountability Journal, 15(3), 312-343.

Dowling, J., \& Pfeffer, J. (1975). Organizational legitimacy: Social values and organizational behavior. Pacific Sociological Review, 18(1), 122-136.

Du, S., \& Vieira, E. T. (2012). Striving for legitimacy through corporate social responsibility: Insights from oil companies. Journal of Business Ethics, 110(4), 413-427.

Elo, S., \& Kyngäs, H. (2008). The qualitative content analysis process. Journal of Advanced Nursing, 62(1), 107-115.

Elsbach, K. D. (1994). Managing organizational legitimacy in the California cattle industry: The construction and effectiveness of verbal accounts. Administrative Science Quarterly, 57-88. 
Erdianto, K. (2017). 'Kronologi Wafatnya Patmi, Petani Kendeng Usai Aksi Dipasung Semen', kompas.com, 21 Maret, downloaded on 5 Oktober 2018, <https://nasional.kompas.com/read/2017/03/21/15294751/kronologi.wafatnya.p atmi.petani.kendeng.usai.aksi.dipasung.semen>

Eugénio, T. P., Lourenço, I. C., \& Morais, A. I. (2013). Sustainability strategies of the company TimorL: extending the applicability of legitimacy theory. Management of Environmental Quality: An International Journal, 24(5), 570-582.

Gephart Jr, R. P. (1978). Status degradation and organizational succession: An ethnomethodological approach. Administrative Science Quarterly, 553-581.

Hannan, M. T., \& Freeman, J. (1984). Structural inertia and organizational change. American Sociological Review, 149-164.

Laine, M. (2005). Meanings of the term 'sustainable development'in Finnish corporate disclosures. In Accounting Forum (Vol. 29, pp. 395-413). Elsevier.

Marcus, A. A., \& Goodman, R. S. (1991). Victims and shareholders: The dilemmas of presenting corporate policy during a crisis. Academy of Management Journal, 34(2), 281-305.

Maurer, J. G. (1971). Readings in organization theory: Open-system approaches. Random House (NY).

Meyer, J. W., \& Rowan, B. (1977). Institutionalized organizations: Formal structure as myth and ceremony. American Journal of Sociology, 83(2), 340-363.

Moneva, J. M., Archel, P., \& Correa, C. (2006). GRI and the camouflaging of corporate unsustainability. In Accounting forum (Vol. 30, pp. 121-137). Elsevier.

O'Donovan, G. (2002). Environmental disclosures in the annual report: Extending the applicability and predictive power of legitimacy theory. Accounting, Auditing \& Accountability Journal, 15(3), 344-371.

O’Dwyer, B., Owen, D., \& Unerman, J. (2011). Seeking legitimacy for new assurance forms: The case of assurance on sustainability reporting. Accounting, Organizations and Society, 36(1), 31-52.

Palazzo, G., \& Scherer, A. G. (2006). Corporate legitimacy as deliberation: A communicative framework. Journal of Business Ethics, 66(1), 71-88.

Parsons, T. (1960). Structure and process in modern societies. Free Pr.

Pfeffer, J. (1981). Management as symbolic action: the creation and maintenance of organizational paradigm. Research in Organizational Behavior, 3, 1-52.

Preston, A. M., Cooper, D. J., Scarbrough, D. P., \& Chilton, R. C. (1995). Changes in the code of ethics of the US accounting profession, 1917 and 1988: The continual quest for legitimation. Accounting, Organizations and Society, 20(6), 507-546.

PT Semen Indonesia Tbk. (2017). Annual Report PT Semen Indonesia Tbk Tahun 2017. Downloaded from http://www.idx.co.id/Portals/0/StaticData/ListedCompanies/Corporate_Actions/ New_Info_JSX/Jenis_Informasi/01_Laporan_Keuangan/04_Annual\%20Report/ /2017/SMGR/SMGR_Annual\%20Report_2017.pdf

Ruef, M., \& Scott, W. R. (1998). A multidimensional model of organizational legitimacy: Hospital survival in changing institutional environments. Administrative Science Quarterly, 877-904. 
Russell, S. L., \& Thomson, I. (2009). Analysing the role of sustainable development indicators in accounting for and constructing a Sustainable Scotland. In Accounting Forum (Vol. 33, pp. 225-244). Elsevier.

Salancik, G. R., \& Meindl, J. R. (1984). Corporate attributions as strategic illusions of management control. Administrative Science Quarterly, 238-254.

Scott, M. B., \& Lyman, S. M. (1968). Accounts. American Sociological Review, 4662.

Scott, W. R. (1977). Effectiveness of organizational effectiveness studies. New Perspectives on Organizational Effectiveness, 63-95.

Scott, W. R. (1981). Rational, natural, and open systems. NJ: Prentice Hall, Englewood Cliff.

Staw, B. M., McKechnie, P. I., \& Puffer, S. M. (1983). The justification of organizational performance. Administrative Science Quarterly, 582-600.

Suchman, M. C. (1995). Managing legitimacy: Strategic and institutional approaches. Academy of Management Review, 20(3), 571-610.

Sutton, R. I., \& Callahan, A. L. (1987). The stigma of bankruptcy: Spoiled organizational image and its management. Academy of Management Journal, $30(3), 405-436$.

Unerman, J. (2000). Methodological issues-Reflections on quantification in corporate social reporting content analysis. Accounting, Auditing \& Accountability Journal, 13(5), 667-681.

Watson, S. (2011). Conflict diamonds, legitimacy and media agenda: an examination of annual report disclosures. Meditari Accountancy Research, 19(1/2), 94-111.

Weber, M. (1978). Economy and society: An outline of interpretive sociology (Vol. 1). Univ of California Press.

Wicaksono, A 2016 'Merendam Kaki di Semen demi Pegunungan Kendeng', cnnindonesia.com, 13 April, downloaded on 5 Oktober 2018, <https://www.cnnindonesia.com/nasional/20160412180316-22123440/merendam-kaki-di-semen-demi-pegunungan-kendeng>

Wood, D. J. (1991). Corporate social performance revisited. Academy of Management Review, 16(4), 691-718.

Zucker, L. G. (1983). Organizations as institutions. Research in the Sociology of Organizations, 2(1), 1-47.

Zucker, L. G. (1986). Production of trust: Institutional sources of economic structure, 1840-1920. Research in Organizational Behavior. 